\section{JURNAL ABDIMAS

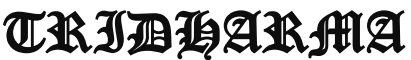

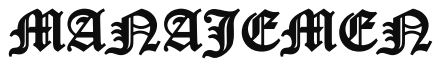

P-ISSN 2715-7105, E-ISSN 2716-070X

Jurnal ABDIMAS Vol. 2, No. 1, Januari 2021,Hal (1-8)

@Prodi Manajemen Fakultas Ekonomi Universitas Pamulang

Email: abdimasjurnal.unpam@gmail.com Telp: (021) 741-2566

\title{
MENINGKATKAN PERAN IBU RUMAH TANGGA DALAM PENGELOLAAN KEUANGAN DI KELURAHAN PONDOK BENDA TANGERANG SELATAN
}

\author{
Bulan Oktrima, Muliahadi Tumanggor, Intan sari Budhiarjo, Arief Rahman \\ Akbar, Ita Darsita \\ Dosen Ekonomi Fakultas Ekonomi Universitas Pamulang \\ Email : dosen00790@unpam.ac.id,dosen00871@unpam.ac.id, \\ dosen02128@unpam.ac.id,dosen02515@unpam.ac.id. \\ dosen02235@unpam.ac.id
}

\begin{abstract}
ABSTRAK
Pengabdian Kepada Masyarakat (PKM) merupakan salah satu darma dari tri dharma perguruan tinggi, maka dari itu melakukan PKM merupakan suatu keharusan bagi Dosen minimal 1 kali dalam satu semester. Dengan demikian, pada kesempatan ini Tim Dosen Prodi Manajemen Unpam melakukan PKM pada Kelurahan Pondok Benda dengan sasarannya adalah Ibu PKK Kelurahan Pondok Benda. Adapun tema yang diangkat adalah "Meningkatkan Peran Ibu Rumah Tangga Dalam Pengelolaan Keuangan Di Kelurahan Pondok Benda, Tangerang Selatan”.

Komponen utama dari masyarakat adalah keluarga yaitu tempat yang nyaman bagi para anggota untuk hidup, beraktifitas dan mencapai kesejahteraan. Peran seorang ibu dalam keluarga sangat penting, terutama untuk mengelola keuangan. Masalah utama yang sering terjadi dalam tata kelola keuangan keluarga, yaitu tidak ada perencanaan kas, penghasilan selalu habis untuk dibelanjakan, minimnya pengetahuan dan keterampilan manajemen keuangan keluarga.

Kegiatan ini bertujuan untuk: 1) meningkatkan pengetahuan dan keterampilan manajemen keuangan dan pengelolaan kas, dan 2) meningkatkan peran ibu rumah tangga dalam pengelolaan keuangan. Pelaksanaan pengabdian dilakukan di kelurahan Lewet kecamatan Amurang, kabupaten Minahasa Selatan. Metode yang digunakan berupa Pendidikan dan Pelatihan Masyarakat, dengan cara: 1) penyuluhan untuk meningkatkan pemahaman serta kesadaran para peserta, 2) demonstrasi untuk menyusun laporan keuangan sederhan, 3) pelatihan untuk membuat perencanaan kas dan mengelola keuangan. Hasil kegiatan menunjukkan bahwa terjadi peningkatan kemampuan para peserta dalam manajemen keuangan keluarga, peningkatan kerampilan dalam perencanaan dan pengelolaan kas, dan peningkatan peran ibu rumah tangga dalam mengendalikan biaya-biaya harian rumah tangga.
\end{abstract}

Keywords: Pengelolaan Keuangan, Manajemen Keuangan, Keluarga 


\section{JURNAL ABDIMAS

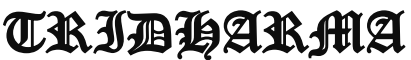

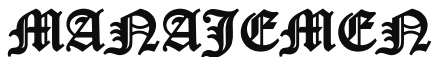

P-ISSN 2715-7105, E-ISSN 2716-070X

Jurnal ABDIMAS Vol. 2, No. 1, Januari 2021,Hal (1-8)

$@$ Prodi Manajemen Fakultas Ekonomi Universitas Pamulang

Email: abdimasjurnal.unpam@gmail.com Telp: (021) 741-2566

\begin{abstract}
The purpose of Community Service Activities is to carry out one of the Tridharma Perguruan Tinggi. In addition, it is expected that through community service, the existence of higher education institutions can make a major contribution to the development and application of knowledge to the community.
\end{abstract}

The method of activity used is that we go to the shcool PKBM Negeri 26 Bintaro having the address at Jl. Bintaro Permai III / 30B, Bintaro, Kec. Pesanggrahan, City Administration of South Jakarta and gave training there on 17-19 October 2019. This training aims to make students and students who attend PKBM Negeri 26 Bintaro especially in the PKBM program be able to increase creativity and innovation utilizing used paper materials that are processed into works that more value and train the entrepreneurial spirit of the students.

The results of community service obtained are increased knowledge for Participants (Students) of the school PKBM Negeri 26 Bintaro so that they have a good view of the importance of increasing creativity and innovation as well as their entrepreneurial spirit or entrepreneurship to become the next generation of the nation, becoming qualified human resources to enter the world work because of how important it is to improve the quality of themselves to face competition in the world of work.

The knowledge gained in Community Service this time is expected to be able to provide new enthusiasm for us in delivering material and motivation and contribute to the young generation, both in schools, colleges, communities and families.

\title{
Keywords: production, economic, entrepreneur
}

\section{PENDAHULUAN}

Pemberdayaan Masyarakat adalah upaya mengembangkan kemandirian dan kesejah-teraan masyarakat dengan meningkatkan pengetahuan, sikap, keterampilan, perilaku, kemampuan, kesadaran, serta memanfaatkan sumber daya melalui serangkaian kebijakan, program, kegiatan dan pendampingan yang sesuai dengan esensi masalah dan prioritas kebutuhan masyarakat. Masyarakat memiliki komponen utama yaitu keluarga. Keluarga memiliki fungsi perlindungan berkaitan dengan dimensi sosial kemasyarakatan, dimana keluarga menjadi satu tempat yang nyaman bagi anggotanya (Astuti \& Winarni, 2018). Dalam tata kelola keuangan keluarga, permasalahan utama yang sering dihadapi adalah: 1) kurangnya pengetahuan dan keterampilan manajemen keuangan ibu rumah tangga, dan 2) dibutuhkan tindakan nyata untuk membantu ibu rumah tangga dalam upaya meningkatkan kemampuan pengelolaan keuangan keluarga secara efektif dan efisien. Solusi untuk mengatasinya adalah memberikan pelatihan manajemen bagi ibu rumah tangga untuk memberikan pengetahuan dan keterampilan manajemen melalui kegiatan perencanaan, 


\section{JURNAL ABDIMAS

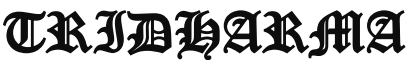

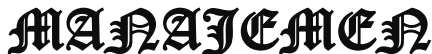

P-ISSN 2715-7105, E-ISSN 2716-070X

Jurnal ABDIMAS Vol. 2, No. 1, Januari 2021,Hal (1-8)

@Prodi Manajemen Fakultas Ekonomi Universitas Pamulang

Email: abdimasjurnal.unpam@ gmail.com Telp: (021) 741-2566 pengorganisasian, pengarahan dan pengawasan terhadap aktivitas produksi, keuangan/ akuntansi, pemasaran dan sumber daya manusia. Setelah mengikuti penyuluhan dan pelatihan ini diharapkan ibu rumah tangga di kelurahan Pondok Benda akan memiliki pengetahuan manajemen dan terampil dalam membuat perencanaan, pengelolaan keuangan/ akuntansi secara sederhana, dan mampu untuk membuat perencanaan anggraan dalam mengelola keuangan rumah tangganya. Penerapan program ini ditempuh dengan cara pelatihan dengan metode studi kasus, latihan-latihan memecahkan masalah tentang Manajemen Modal Usaha dan Pengelolaan Kas.

Banyak orang beranggapan bahwa Manajemen keuangan keluarga merupakan salah satu bidang yang rumit. Sebenarnya manajemen keuangan keluarga tidaklah rumit seperti yang dibayangkan banyak orang, khususnya ibu-ibu yang sering di daulat sebagai manajer keuangan keluarga. Untuk menjadi manajer keuangan keluarga yang cerdas dan bijak, tidaklah harus menjadi seorang ahli keuangan.

Manajemen keuangan keluarga memang membutuhkan pengetahuan dan kearifan dalam menjalankannya. Kebanyakan orang yang merasa terintimidasi dengan masalah ini, malah mengabaikannya. Persoalaan ini harusnya menjadi prioritas keluarga karena banyak sekali masalah timbul karena kurang bijaknya manajer keuangan keluarga dalam mengelola dan mengatur keuangannya. Sebagai seorang manajer keuangan keluarga, ada beberapa aspek yang perlu ditangani yaitu: Membuat dan meninjau secara perisodik prioritas keuangan keluarga, Mengelola pendapatan yang terbatas

secara bijakMenghitung kebutuhan proteksi serta menginvestasikan dana dalam bentuk investasi yang sesuai, Menentukan sebuah rencana pension, Mempersiapkan dana pendidikan untuk anak-anak, Belanja dengan bijak, Mengajarkan anak-anak mengenai keuangan.

\section{RUMUSAN MASALAH}

Adapun rumusan masalah dalam PKM ini adalah:

1. Bagaimana Peran Ibu Rumah Tangga Di Kelurahan Pondok Benda?

2. Bagaimana Pengelolaan Keuangan keluarga?

3. Bagaimana Ibu Rumah Tangga di kelurahan Pondok Benda dalam mengelola keuangan?

\section{TUJUAN PELAKSANAAN}

\section{Adapun tujuan dari kegiatan}

Pengabdian Kepada Masyarakat adalah:

1. Untuk mengetahui Peran Ibu Rumah Tangga Di Kelurahan Pondok Benda.

2. Untuk mengetahui Pengelolaan Keuangan keluarga.

3. Untuk mengetahui Ibu Rumah Tangga di kelurahan Pondok Benda dalam mengelola keuangan.

\section{TINJAUAN PUSTAKA}

1. Pengertian Keuangan

Manajemen merupakan proses penting dalam suatu organisasi atau perusahaan. Dengan menggunakan manajemen yang baik, maka tujuan perusahaan dapat tercapai sesuai rencana yang ditetapkan. 


\section{JURNAL ABDIMAS

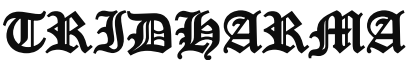

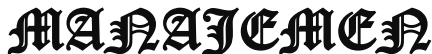

P-ISSN 2715-7105, E-ISSN 2716-070X

Jurnal ABDIMAS Vol. 2, No. 1, Januari 2021,Hal (1-8)

@ Prodi Manajemen Fakultas Ekonomi Universitas Pamulang

Email: abdimasjurnal.unpam@ gmail.com Telp: (021) 741-2566
Menurut Malayu S.P. Hasibuan (2012) mengatakan bahwa manajemen adalah ilmu dan seni yang mengatur proses pemanfaatan sumber daya manusia dan sumber-sumber lainnya secara efektif dan efisien untuk mencapai tujuan tertentu

Pengertian keuangan adalah "Finance can be defined as the science and art of manging money", yang artinya adalah keuangan dapat didefinisikan sebagai seni dan ilmu pengetahuan dari pengelolaan uang. Sesungguhnya setiap individu dan organisasi menghasilkan uang dan membelanjakan atau menginvestasikan uang. Keuangan berhubungan dengan proses, institusi, pasar, dan instrument yang terlibat dalam perpindahan atau transfer uang antar individu, bisnis, dan pemerintah Gitman (2015:5).

Dari definisi keuangan tersebut maka dapat dikembangkan bahwa keuangan sebagai seni berarti melibatkan keahlian dan pengalaman. Sedangkan sebagi ilmu berarti melibatkan prinsip-prinsop, konsep, teori, proposi, dan model yang ada dalam ilmu keuangan yang mempelajari tentang bagaimana pengelolaan uang, dimana keuanagan sangan berpengaruh dalam kehidupan setiap manusia.

\section{Pengertian Manajemen Keuangan Keluarga}

Untuk dapat menjalankan roda kehidupan keluarga secara bijak, pentingnya bagi sebuah keluarga untuk menjalankan tiga langkah berikut ini, (Iswandi dan Saiful Amiq, 2013):

a. Mengidentifikasi

dan

Menetapkan

Prioritas

Keuangan.

Menentukan prioritas keuangan secara spesifik merupakan langkah awal dalam sebuah menajemen keuangan keluarga. Menentukan prioritas keuangan keluarga yang sesuai dengan keinginan masing-masing anggota keluarga membutuhkan perbincangan yang dalam. Dibutuhkan keterbukaan serta kesepakatan anggota keluarga khususnya ibu dan bapak yang akan membawa atau memimpin keluarga.

b. Memikirkan dan Mengembangkan Sebuah Rencana Pencapaian. Saat seseorang telah menetapkan prioritas tujuan keuangan keluarga, maka ia memerlukan sebuah stratetgi atau perencanaan yang harus dilakukan agar prioritas tersebut tercapai. Karena kondisi dan situasi keuangan setiap keluarga berbeda, maka berikut ini akan di uraikan gambaran umum seputar hal-hal yang sebaikanya dialakukan dalam melihat strategi atau perencanaan keuangan keluarga.

a) Diperlukan sebuah anggaran belanja. Penganggaran merupakan salah satu bagian terpenting dalam mengelola keuangan keluarga. Dengan anggaran belanja akan membantu untuk mengenali kemungkinan masalahmasalah yang akan timbul dalam pola pengeluaran. Dengan begitu, dapat dicari cara-cara mengatasi masalah tersebut.

b) Miliki sebuah perencanaan menabung. Selama ini kita mengenal pola menabung hanya dari sisa belanja bulanan. Itu merupakan cara 


\section{JURNAL ABDIMAS

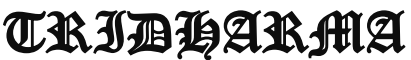

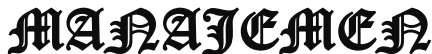

P-ISSN 2715-7105, E-ISSN 2716-070X

Jurnal ABDIMAS Vol. 2, No. 1, Januari 2021,Hal (1-8)

@Prodi Manajemen Fakultas Ekonomi Universitas Pamulang

Email: abdimasjurnal.unpam@gmail.com Telp: (021) 741-2566 yang sangat kuno dan tidak efektif. Sekarang alokasi menabung itu harus masuk sebagai pengeluaran rutin yang harus didahulukan. Karena kalau menunggu sisa, seringkali tidak ada sisanya di akhir bulan.

c) Bijak mengambil hutang. Paling tidak ada tiga (3) petunjuk dasar yang di butuhkan dalam mempertimbangkan

pinjaman yang akan di ambil. Pertama, Jangan pernah meminjam lebih besar dari kemampuan keuangan. Kedua, Jangan pernah meminjam untuk kebutuhan barang-barang mewah, seperti mobil mewah, perhiasan, bila dengan hal itu tidak dapat meminjam untuk kebutuhan keluarga seperti, pinjaman kredit rumah atau pinjaman pribadi untuk biaya sekolah anak. Ketiga, harus di Pastikan bahwa masih menyisakan kapasitas dalam meminjam untuk kebutuhankebutuhan yang tidak terduga.

d) Alokasikan dana untuk mencapai prioritas tujuan keuangan yang dimiliki. Setiap keluarga pasti memiliki tujuan yang berbeda. Berdasarkan prioirtas tujuan tersebut alokasikan dana untuk menacapinya. Contoh dari tujuan keuangan keluarga seperti menyiapkan dnaa pendidikan anak, masa pensiun dan lain-lain.

\section{c. Mengembangkan Prosedur Pelaksanaan Perencanaan \\ Bekerja sebagai sebuah tim} (keluarga) dalam menajeman keuangan keluarga dapat mengurangi atau menangkis sumber permasalahan dan kesalahpahaman. Walaupun penetapan tujuan serta pengembangan perencanaan telah dilakukan, kita harus memutuskan siapa yang melaksanakan rencana atau apa yang menjadi prosedur pelaksaan perencanaan yang telah disepakati bersama.

Dalam sebuah keluarga mungkin antara suami-istri bisa membagi tanggung jawab. Misalkan keduanya bekerja (suami dan istri), dapat dibagi siapa yang bertanggung jawab terhadap tagihan-tagihan yang ada. Misalkan, istri lebih memprioritaskan untuk memenuhi anggaran belanja bulanan. Sedangkan suami bertanggung jawab untuk biaya listrik, telp, tabungan pendidikan, pensiun dan lain-lain.

\section{METODE PELAKSANAAN}

Adapun tempat dan waktu pelaksanaan kegiatan Pengabdian Kepada Masyarakat ini di lakukan di Kantor Kelurahan Pondok Benda beralamat Alamat Pondok Benda: Jl. Siliwangi No.1 Pondok Benda, Kecamatan Pamulang, Kota Tangerang Selatan, Banten 15416 terhitung tanggal 2-4 November 2020.

Dalam melaksanakan kegiatan PKM ini digunakan beberapa metode yaitu:

1. Metode Ceramah / Presentasi, Metode ceramah/presentasi dipilih untuk memberikan penjelasan mengenai:

a. Memberikan pengetahuan terkait dengan 


\section{JURNAL ABDIMAS

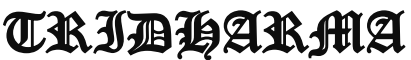

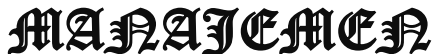

P-ISSN 2715-7105, E-ISSN 2716-070X

Jurnal ABDIMAS Vol. 2, No. 1, Januari 2021,Hal (1-8)

@Prodi Manajemen Fakultas Ekonomi Universitas Pamulang

Email: abdimasjurnal.unpam@ gmail.com Telp: (021) 741-2566 memanajemen keuangan keluarga yang baik dan benar

b. Memberikan pengetahuan terkait dengan cara meminimalisir pengeluaragan keuangan keluarga secara efektif

c. Memberikan pengetahuan terkait dengan cara menumbuhkan minat menabung bagi Ibu-Ibu Rumah Tangga

2. Metode Tanya Jawab

Metode Tanya jawab sangat penting bagi para peserta. Metode ini memungkinkan para ibu PKK menggali pengetahuan sebanyakbanyaknya tentang Pentingnya Manajemen Keuangan Keluarga Pada Ibu Ibu Rumah Tangga Kelurahan Pondok Benda.

3. Sharing Session. Tentang Pentingnya Manajemen Keuangan Keluarga Pada Ibu Ibu Rumah Tangga Kelurahan Pondok Benda Guna Meminimalisir Pengeluaran.

\section{HASIL DAN PEMBAHASAN}

Berdasarkan wawancara, tanya jawab dan pengamatan langsung selama kegiatan berlangsung, kegiatan pengabdian pada masyarakat ini memberikan hasil sebagai berikut :

a. Memberikan pengetahuan kepada Ibu-Ibu Rumah Tangga di kelurahan Pondok Benda mengenai peran nya sebagai Ibu Rumah Tangga.

b. Memberikan pengetahuan kepada Ibu-Ibu Rumah Tangga di kelurahan Pondok Benda mengenai Manajemen Keuangan. c. Memberikan gambaran dan pengetahuan kepada Ibu-Ibu Rumah Tangga di kelurahan Pondok Benda dalam pengelolaan keuangan keluarga.

Beberapa faktor yang mendukung terlaksananya kegiatan pengabdian pada masyarakat ini adalah besarnya minat dan antusiasme peserta selama kegiatan, sehingga kegiatan berlangsung dengan lancar dan efektif. Sedangkan faktor penghambatnya adalah keterbatasan waktu pelatihan dan fasilitas peralatan yang masih minim.

\section{KESIMPULAN DAN SARAN}

\section{Kesimpulan}

Dari kegiatan pengabdian pada masyarakat ini dapat disimpulkan bahwa:

1. Pengetahuan dan pemahaman Ibu-Ibu Rumah Tangga Kelurahan Pondok Benda tentang perannya sebagai Ibu Rumah Tangga.

2. Semakin meningkatnya ide dan kreatifitas bunga hias dalam menciptakan peluang usaha yang bernilai ekonomis.

\section{Saran}

Mengingat besarnya manfaat kegiatan pengabdian pada masyarakat ini, maka selanjutnya perlu:

1. Mengadakan sosialisasi dan pelatihan serupa pada siswa sekolah lain di Kecamatan yang lain, dengan materi yangserupa.

2. Adanya kesinambungan program pasca kegiatan pengabdian ini sehingga para siswa benar-benar dapat memproduksi bunga hias dengan 


\section{JURNAL ABDIMAS

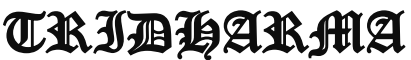

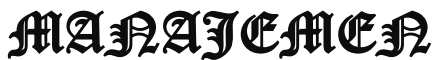

P-ISSN 2715-7105, E-ISSN 2716-070X

Jurnal ABDIMAS Vol. 2, No. 1, Januari 2021,Hal (1-8)

@Prodi Manajemen Fakultas Ekonomi Universitas Pamulang

Email: abdimasjurnal.unpam@gmail.com Telp: (021) 741-2566 bahan kertas bekas dalam menciptakan peluang usaha yang bernilai ekonomis

\section{DAFTAR PUSTAKA}

Iswandi dan Saiful Amiq, 2013, "Manajemen Keuangan Keluarga" Artikel Online https://juraganmakalah.blogspot.com/2 013/03/manajemen-keuangan-keluargai.html (Diakses Hari Selasa 6 Oktober 2020)

Kasmir (2010) , Pengantar Manajemen Keuangan. Edisi Kedua, Penerbit: Kencana Prenada Media Group, Jakarta.

Love Life Daily, 2020, "Manajemen Keuangan bagi Lajang dan Keluarga Baru di Era New Normal" Artikel Onlinehttps://ilovelife.co.id/blog/manaj emen-keuangan-bagi-lajang-dankeluarga-baru-di-era-new-normal/. (Diakses Hari Selasa 6 Oktober 2020).

Gitman, Lawrence, J.(2015). Principles of Manajerial Finance. International Edition, 10th edition, Pearson Education, Baston.

Hasibuan, Malayu S.P. (2012). Manajemen Sumber Daya Manusia. Jakarta : PT.Bumi Aksra.

Pasaribu, V. L. D., Susanti, F., \& Hartuti, E. T. K. (2019). Memotivasi Siswa dan Siswi SMK Letris Indonesia di Dalam Menentukan Pilihan Untuk Melanjutkan Pendidikan Atau Bekerja Setelah Lulus Sekolah. Jurnal Pengabdian Dharma Laksana, 1(2), 161-172.

Pasaribu, V. L. D., Agrasadya, A., Shabrina, N., \& Krisnaldy, K. (2020). MENJADI ENTERPRENEUR MUDA YANG MEMILIKI JIWA LEADERSHIP UNTUK MENGHADAPI MASA DEPAN. $A b d i$ Laksana, 1(1).
Pasaribu, V. L. D., Elburdah, R. P., Sudarso, E., \& Fauziah, G. (2020). PENGGUNAAN MANAJEMEN WAKTU TERHADAP PENINGKATAN PRESTASI BELAJAR DI SMP ARAISIYAH. Jurnal ABDIMAS Tri Dharma Manajemen, 1(1).

Pasaribu, V. L. D., Sulaiman, S., Sutiman, S., Thaharudin, T., \& Purnomo, B. Y. (2020). PENGENALAN LETAK POSYANDU TERDEKAT DIKELURAHAN PISANGAN DENGAN MANAJEMEN PEMASARAN REVOLUSI 4.0 UNTUK MENINGKATKAN PENGETAHUAN MASYARAKAT LETAK DAN FUNGSI POSYANDU TERDEKAT PADA KELURAHAN PISANGAN. DEDIKASI PKM, 1(1), 105-110.

Pasaribu, V. L. D., Oktrima, B., Prabowo, B., Arianto, N., \& Haryoko, U. B. (2020). PROGAM PENDAMPINGAN DAN PENYELENGGARAAN PENDIDIKAN ANAK PADA USIA DINI TERHADAP PRESTASI BELAJAR DILINGKUNGAN RT 020 RW 009. KEL GIRI PENI. KEC WATES. YOGYAKARTA. JURNAL LOKABMAS KREATIF, 1(1), 71-75.

\section{DOKUMENTASI FOTO KEGIATAN}

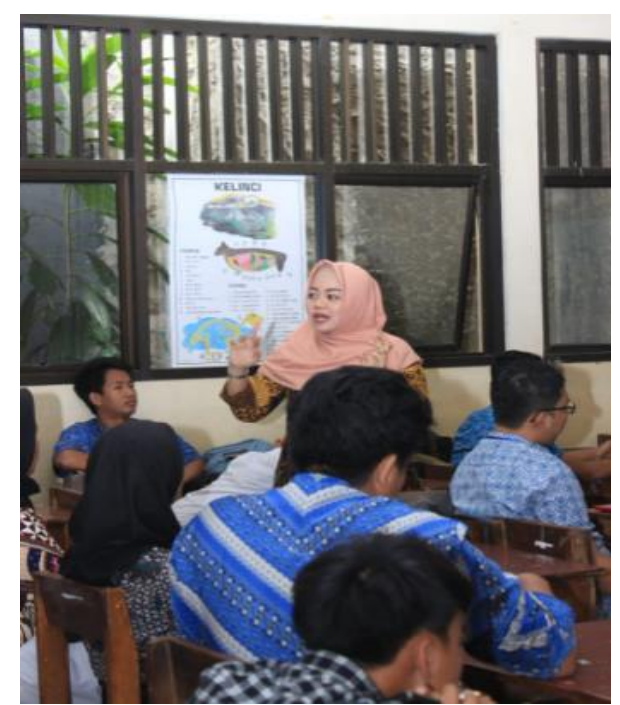


JURNAL ABDIMAS

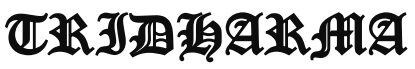

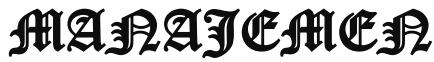

P-ISSN 2715-7105, E-ISSN 2716-070X

Jurnal ABDIMAS Vol. 2, No. 1, Januari 2021,Hal (1-8)

@Prodi Manajemen Fakultas Ekonomi Universitas Pamulang

Email: abdimasjurnal.unpam@gmail.com Telp: (021) 741-2566

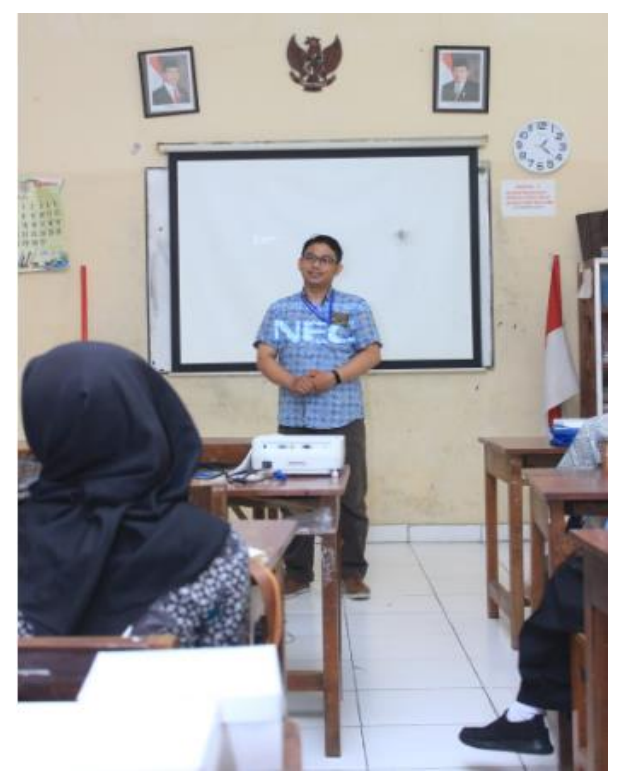

